\title{
AKTUALISASI NILAI-NILAI PANCASILA DALAM PERJANJIAN PRA-KONTRAK SEBAGAI IUS CONTITUENDUM HUKUM PERJANJIAN NASIONAL
}

\author{
Oleh: \\ Nursaiful Afandi \\ Email: nsafandi001@gmail.com \\ Universitas Narotama Surabaya
}

\begin{abstract}
Abstrak
Tulisan ini bertujuan untuk menakar apakah sejatinya selama ini sudah mampu teraktualisasikan dalam praktik kontrak di Indonesia. Selain itu, tulisan ini juga memperlihatkan kondisi jikalau nilai-nilai yang terkandung dalam pancasila mampu diterapkan dalam perjanjian pra-kontrak di Indonesia. Penulisan ini menggunakan metode yuridis normatif. Melalui pendekatan peraturan perundang-undangan (statute approach) dan pendekatan konseptual (conseptual approuch) tulisan ini mencoba menjawab problematika dan potensi penerapan nilai-nilai pancasila dalam perjanjian pra-kontrak. Hasil penelitian menyatakan, aktualisasi nilai-nilai pancasila dalam kerangka konseptual mampu menyentuh nilai dasar, nilai intrumental dan nilai praksis. Kesulitan aktualisasi nilai-nilai Pancasila dalam tataran praksis mempunyai tantangan tersenidri. Satu sisi Pancasila sebagai pandangan hidup bangsa (way of life), namun disisi lain ada beberapa deviasi-deviasi terhadapnya termasuk dalam hal ini deviasi nilai-nilai pancasila dalam praktek pra-kontrak.
\end{abstract}

Kata Kunci : Pancasila; Perjanjian; Prakontrak;

\begin{abstract}
This paper aims to assess whether the truth has been able to be actualized in contract practices in Indonesia. In addition, this paper also shows the conditions if the values contained in Pancasila can be applied in pre-contractual agreements in Indonesia. This writing uses the normative juridical method. Through the statutory approach and the conceptual approach (conceptual approuch) this paper tries to answer the problematics and potential application of Pancasila values in pre-contractual agreements. The results of the study stated, the actualization of the values of Pancasila within the conceptual framework was able to touch the basic values, internal values and praxis values. The difficulty of actualizing Pancasila values at the praxis level has a particular challenge. One side of the Pancasila as the way of life, but on the other hand there are some deviations towards it, including in this case the deviation of the values of the Pancasila in pre-contract practice.
\end{abstract}

Keywords: Pancasila; Agreement; Precontract; 


\section{PENDAHULUAN}

\subsection{Latar Belakang}

Pancasila sebagai falasafah hidup bangsa yang merupakan kesepakatan para founding fathers ketika negara Indonesia didirikan. Keberadaan Pancasila tidak semerta-merta muncul begitu saja, proses panjang dan melalui perdebatan yang keras sehingga terbentuk falsafah hidup bangsa yang berjumlah lima (5) sila dengan poros ketuhanan yang maha esa yang diusung oleh semangat gotong royong antar warga negara. Hadirnya pancasila dicita-citakan sebagai filsafat negara (pilosopische grondlag) agar dapat diaktualisasikan dalam setiap kehidupan berbangsa dan bernegara. Sejatinya semangat ini senantiasa harus dijaga oleh para penerus bangsa, namun dalam perjalanan panjang kehidupan berbangsa dan bernegara, Pancasila sering mengalami berbagai deviasi dalam aktualisasi nilai-nilainya. Deviasi pengamalan Pancasila tersebut bisa berupa penambahan, pengurangan, dan penyimpangan dari makna yang seharusnya. Walaupun seiring dengan itu sering pula terjadi upaya pelurusan kembali. ${ }^{1}$

Yudistira (Fakultas Hukum, Universitas Muhammadiyah Palembang Sumatera Selatan), Aktualisasi dan Implementasi Nilai-Nilai Pancasila dalam Menumbuh Kembangkan Karakter Bangsa, Seminar Nasional Hukum (Fakultas Hukum UNNES)Volume 2 Nomor 1 Tahun 2016, 426
Pancasila sering digolongkan ke dalam ideologi tengah di antara dua kutub yaitu komunisme dan kapitalisme. Posisi Pancasila inilah yang merepotkan aktualisasi nilai-nilainya kedalam kehidupan praksis berbangsa dan bernegara. Dinamika aktualisasi nilai Pancasila bagaikan pendulum (bandul jam) yang selalu bergerak kekanan dan kekiri secara seimbang tanpa pernah berhenti tepat di tengah dan begitu fluktuatif. ${ }^{2}$

Mulai berdirinya bangsa indonesia, Masa Orde Lama (Soekarno), Orde Baru (Soeharto), dan masa reformasi, senantiasa bergerak kekiri dan kekanan menunjukkan ideologi Pancasila mengalami deviasideviasi dari harapan para pembentuknya. Selanjutnya pemerintahan-pemerintahan rezim reformasi ini semestinya mampu memberikan koreksi terhadap penyimpangan dalam mengamalkan Pancasila dan UUD 1945 dalam praktik bermasyarakat dan bernegara yang dilakukan oleh Orde Baru.

Ideologi Pancasila sebagai ruh dan nafas bangsa Indonesia mempunyai tiga (3) tataran nilai meliputi nilai dasar, nilai instrumental dan nilai praksis. Jikalau ditelaah dari perspektif pelaksanaan nilai yang dianut, maka sesungguhnya pada nilai praktislah ditentukan tegak atau tidaknya nilai dasar dan nilai instrumental itu. Secara

${ }^{2}$ Ibid, 421 
singkat bukan pada rumusan abstrak, dan bukan juga pada kebijaksanaan, strategi, rencana, program atau proyek itu sendiri terletak batu ujian terakhir dari nilai yang dianut, tetapi pada kualitas pelaksanaannya di lapangan. Bagi suatu ideologi, yang paling penting adalah bukti pengamalannya atau aktualisasinya dalam kehidupan bermasyarakat, berbangsa, dan bernegara.

Suatu ideologi dapat mempunyai rumusan yang amat ideal dengan ulasan yang amat logis serta konsisten pada tahap nilai dasar dan nilai instrumentalnya. Akan tetapi, jika pada nilai praksisnya rumusan tersebut tidak dapat diaktualisasikan, maka ideologi tersebut akan kehilangan kredibilitasnya. ${ }^{3}$ Bahkan tantangan terbesar bagi suatu ideologi adalah menjaga konsistensi antara nilai dasar, nilai instrumental, dan nilai praksisnya.

Agaknya kesulitan aktualisasi nilainilai ini juga tumbuh dan mengakar dalam sistem hukum di Indonesia. Semangat aktualisasi nilai-nilai pancasila tidak secara utuh dapat masuk ke dalam sistem hukum di Indonesia, terlebih dalam hal pengaturan aturan perundang-undangan yang belum dinasionalisasi seperti yang digagas pada awal kemerdekaan. Menurut pasal 7 Undang-Undang Nomor 12 Tahun 2011 Tentang Pembentukan Peraturan Perundang-Undangan menytakan bahwa

\footnotetext{
${ }^{3}$ Ibid, 426
}

hiraki peraturan perundang-undangan hanya terbatas pada pasal tersebut, dan seluruh produk hukum selain yang tercantum dalam pasal tersebut, tidak ada cara lain selain dengan cara disesuaikan.

Namun pada faktanya ada beberapa peraturan perundang-undangan yang belum sesuai dengan pasal tersebut, seperti halnya pengaturan hukum perdata yang masih menggunakan produk kolonial yang berawal dari Bugerlikje Wetbook atau sering disebut BW yang saat ini menjadi Kitab Undang-Undang Hukum Perdata (KUH Perdata). Norma-norma atau pasalpasal dalam KUH Perdata masih berciri khas kolonial bahkan sebelum BW diperbarui menjadi NBW, dengan kata lain nilai-nilai pancasila belum masuk kedalam pasal-pasal tersebut, meskipun tidak sama sekali pasal-pasal tersebut inkonstitusional.

Selain itu permasalah yang masih menggurita dalam hukum perdata adalah hukum yang belum mampu mengakomodir praktek-praktek atau peristiwa kongkrit yang terjadi dimasyarakat. Perihal permasalah teknis mengenai perluasan klausula kontrak yang terdapat dalam pasal 1313, diperluas pemaknaanya sehingga prakontrak masuk kedalam klausula tersebut. Perbandingan yang kentara ketika kontrak dan pra-kontrak disandingkan terlebih dalam hal pengertiannya. Perjnajian atau kontrak diatur Pasal 1313 KUHPerdata yang berbunyi "Perjanjian adalah suatu 
perbuatan dengan mana satu pihak atau lebih mengikatkan dirinya terhadap satu orang atau lebih." Sedangkan pra kontrak merupakan tahap sebelum kontrak dirancang dan disusun. Dalam Black Law Dictionary pengertian pra kontrak adalah "Precontractual is a contract that precludes a party from entering into comparable agreement with someone else."

Nota Kesepahaman atau juga biasa disebut dengan Memorandum of Understanding (MoU) atau pra-kontrak, pada dasarnya tidak dikenal dalam hukum konvensional di Indonesia. Akan tetapi dalam praktiknya, khususnya bidang komersial, $M o U$ sering digunakan oleh pihak yang berkaitan. Kemudian dari praktek inilah menimbulkan beberapa permasalahan. Selain tidak ada satupun justifikasi terhadap praktek tersebut dalam peraturan perundang-undangan di Indonesia atau vacum of norm, sehigga terhadap akibat hukum dari pra-kontrak belum diperhitungkan apabila terjadi kerugian yang nyata akibat salah satu pihak tidak beriktikad baik.

Berangkat dari permasalahan ini dan pentingnya pula aktualisasi nilai-nilai pancasila dalam kehidupan berbangsa dan bernegara, perlunya digagas Hukum Perjanjian Nasional sebagai ius constituendum yang sesuai ruh dan nafas Pancasila sehingga pra-kontrak mempunyai kekuatan mengikat layaknya kontrak.

\subsection{Rumusan Masalah}

a. Bagaimana pelaksanaan pra-kontrak di Indonesia?

b. Bagaimana implikasi nilai-nilai pancasila dalam hukum kontrak di Indonesia?

\section{PEMBAHASAN}

\subsection{Pra-Kontrak dalam Hukum Kontrak di Indonesia}

Pancasila sebagai dasar negara oleh Soekarno berdasarkan usulan telah disepakati secara aklamasi dan diterima oleh para anggota BPUPKI waktu itu yang kemudian disempurnakan secara bersamasama agar lebih sistematis. Oleh sebab itu, sebelum sidang pertama berakhir dibentuklah panitia kecil untuk merumuskan dasar negara berdasarkan pidato yang diucapkan Bung Karno pada 1 Juni 1945 serta berdasarkan pandangan-pandangan yang disampaikan oleh para anggota BPUPK dalam rangkaian Sidang Pertama. Panitia kecil tersebut beranggotakan delapan orang yang kemudian diketuai oleh Soekarno sendiri. Di tengah rangkaian proses merumuskan dasar negara itu, Soekarno memiliki inisiatif untuk membentuk panitia kecil guna mempercepat dirumuskannya dasar negara. Panitia kecil bentukan Soekarno beranggotakan sembilan orang yang kemudian dikenal dengan sebutan Panitia Sembilan. Panitia Sembilan 
menghasilkan rancangan Pembukaan yang kemudian dikenal dengan sebutan Piagam Jakarta. $^{4}$

Meskipun Pancasila usulan Soekarno tersebut sudah mendapat persetujuan mutlak oleh para founding fathers, bahkan kemudian dikaji secara sistematis oleh panitia khusus, akan tetapi secara konstitusional rumusan Pancasila yang hingga saat ini dikenal ditetapkan baru pada 18 Agustus 1945 oleh PPKI. Menariknya, pada waktu ditetapkan, pad Alinea Keempat Pembukaan UUD 1945 mengalami perubahan pada rumusan sila pertama Pancasila yaitu dengan mencoret bagian kalimat "dengan kewajiban menjalankan syariat Islam bagi pemeluk-pemeluknya”. 5 Dengan demikian, sila pertama menjadi Ketuhanan Yang Maha Esa sebagaimana dalam rumusan kelima menurut pidato Soekarno.

\footnotetext{
${ }^{4}$ Mohammad Hatta dkk, Uraian Pancasila, Jakarta: Mutiara, 1978.

${ }^{5}$ Dalam Piagam Jakarta, sila pertama Pancasila berbunyi "Ketuhanan, dengan kewajiban menjalankan syari'at Islam bagi pemelukpemeluknya". Setelah dicoret tujuh kata itu maka jadilah "Ketuhanan Yang Maha Esa". Lihat Mohammad Hatta dkk, ibid, h.77 dalam notulensi sidang 1 panitia 5 tanggal 10 januari 1975 pukul 09.15 di kediaman bung hatta jl. Diponegoro jakarta. Terkait Piagam Jakarta, sebenarnya terdapat tiga sebutan yang berbedabeda yaitu Soekarno menyebutnya Mukadimmah, Yamin menamakannya Piagam Jakarta dan Soekiman menyebutnya Gentlement Agreement. Jadi, nama yang terkenal adalah nama yang diberikan Moh. Yamin. Lihat A.B Kusuma, Op. Cit.,h. 472
}

Sebelum rumusan Pancasila sebagaimana yang kita ketahui saat ini terdapat beberapa usulan rumusan. Setidaknya penulis menemukan ada tiga usulan yang kemudian disampaikan dalam sidang BPUPKI. Sidang Pertama Badan Penyelidik Usaha-usaha Persiapan Kemerdekaan (BPUPKI) memberikan Moh. Yamin kesempatan pertama untuk menyampaikan usulannya. Pidato tersebut disampaikan pada tanggal 29 Mei 1945, ${ }^{6}$ dan dalam pidato tersebut berisi lima (5) usulan Dasar Negara Indonesia dengan sebutan Pancadharma yaitu: 1) Peri Kebangsaaan; 2) Peri Kemanusiaan; 3) Peri Ke-Tuhanan; 4) Peri Kerakyatan dan 5) Peri Kesejahteraan Rakyat. Selang dua hari berikutnya atau lebih tepatnya pada tanggal 31 Mei 1945, giliran Soepomo yang mendapat kesempatan untuk menyampaikan usulan pidatonya yang berisi: ${ }^{7}$

"Dalam suasana persatuan antara rakyat dan pemimpinnya, antara golongan-golongan rakyat sama lain, segala golongan diliputi oleh semangat gotong royong, semangat kekeluargaan. Maka teranglah Tuantuan yang terhormat bahwa jika kita hendak mendirikan negara Indonesia

\footnotetext{
${ }^{6}$ Sidang dimulai 29 Mei-1 Juni 1945, agenda persidangan adalah menyampaikan pandangan mengenai dasar negara Indonesia merdeka. Tepat pada sidang hari keempat, Soekarno mengemukakan Pancasila yang disambut tepuk tangan riuh peserta sidang. Lihat pidato selengkapnya dalam A.B Kusuma, Lahirnya Undang-Undang Dasar 1945, Jakarta: Badan Penerbit Fakultas Hukum Universitas Indonesia, 2004, h.150-167.
} 
yang sesuai keistimewaan sifat dan corak masyarakat Indonesia, maka negara kita harus berdasar atas aliran pikiran (staatsidee) negara yang integralistik, negara yang bersatu dengan seluruh rakyatnya, yang mengatasi seluruh golongan-golongannya dalam lapangan apapun.."

Realitas alam selalu mengalami proses atau perubahan, yaitu kemajuan, kreatif dan baru. ${ }^{8}$ Realitas itu sangatlah dinamis dan suatu proses yang terus menerus "menjadi", walaupun unsur permanen realitas dan identitas diri dalam perubahan tidak boleh diabaikan begitu saja. Sifat alamiah itu dapat pula dikenakan pada ideologi Pancasila sebagai suatu realitas (pengada). Pertanyaanya, bagaimana nilai-nilai Pancasila itu mampu teraktualisasikan dalam praktik kehidupan berbangsa dan bernegara? dan, unsur nilai Pancasila manakah yang seharusnya dapat dipertahankan tanpa mengenal perubahan.

Jika ditinjau dari segi pelaksanaan nilai yang dianut, maka sesungguhnya pada nilai praksislah ditentukan tegak atau tidaknya nilai dasar dan nilai instrumental itu. Ringkasnya bukan pada rumusan abstrak, dan bukan juga pada kebijaksanaan, strategi, rencana, program atau proyek itu sendiri terletak batu ujian terakhir dari nilai yang dianut, tetapi pada kualitas

8 Yudistira (Fakultas Hukum, Universitas Muhammadiyah Palembang Sumatera Selatan), Aktualisasi dan Implementasi Nilai-Nilai Pancasila dalam Menumbuh Kembangkan Karakter Bangsa, 424 pelaksanaannya di lapangan. Bagi suatu ideologi, yang paling penting adalah bukti pengamalannya atau aktualisasinya dalam kehidupan bermasyarakat, berbangsa, dan bernegara. Suatu ideologi dapat mempunyai rumusan yang amat ideal dengan ulasan yang amat logis serta konsisten pada tahap nilai dasar dan nilai instrumentalnya.

Artinya, nilai-nilai yang terkandung dalam Pancasila merupakan nilai-nilai yang dicita-citakan dan ingin diwujudkan. Masalah aktualisasi nilai-nilai dasar ideologi Pancasila ke dalam kehidupan praksis kemasyarakatan dan kenegaraan bukanlah masalah yang sederhana, masih terdapat beberapa kekeliruan yang mendasar dalam cara orang memahami dan menghayati Negara Pancasila dalam berbagai seginya. ${ }^{9}$ Kiranya tidak tepat membuat "sakral" dan tabu berbagai konsep dan pengertian, seakan-akan sudah jelas betul dan pasti benar, tuntas dan sempurna, sehingga tidak boleh dipersoalkan lagi.

Belum teraktualisasinya nilai dasar Pancasila secara konsisten dalam tataran praksis perlu terus menerus diadakan perubahan, baik dalam arti konseptual maupun operasional. Banyak hal harus ditinjau kembali dan dikaji ulang. Beberapa mungkin perlu dirubah, beberapa lagi mungkin perlu dikembangkan lebih lanjut dan dijelaskan atau diperjelas, dan beberapa

\footnotetext{
${ }^{9}$ Ibid
} 
lagi mungkin perlu ditinggalkan.

Aktualisasi nilai Pancasila dituntut selalu mengalami pembaharuan. Hakikat pembaharuan adalah perbaikan dari dalam dan melalui sistem yang ada. Atau dengan kata lain, pembaharuan mengandaikan adanya dinamika internal dalam diri Pancasila.

Oleh karena itu, Pancasila perlu dijabarkan secara rasional dan kritis agar membuka iklim hidup yang bebas dan rasional pula. Konsekuensinya, bahwa Pancasila harus bersifat terbuka. Artinya, peka terhadap perubahan yang terjadi dalam kehidupan manusia dan tidak menutup diri terhadap nilai dan pemikiran dari luar yang memang diakui menunjukkan arti dan makna yang positif bagi pembinaan budaya bangsa, sehingga dengan demikian menganggap proses akulturasi sebagai gejala wajar. Dengan begitu ideology Pancasila akan menunjukkan sifatnya yang dinamik, yaitu memiliki kesediaan untuk mengadakan pembaharuan yang berguna bagi perkembangan pribadi manusia dan masyarakat. Untuk menghadapi tantangan masa depan perlu didorong pengembangan nilai-nilai Pancasila secara kreatif dan dinamik.

Tahap pra kontrak merupakan tahap sebelum kontrak dirancang dan disusun. Dalam Black Law Dictionary pengertian pra kontrak adalah: "Precontractual is a contract that precludes a party from entering into comparable agreement with someone else."
Dalam masyarakat pengusaha (bisnis) tahap pra kontraktual sering disamakan dengan Memorandum Of Understandings (MoU) sebelum masuk atau mengikatkan diri ke dalam kontrak yang mengikat. Memorandum of Understandings (MOU) atau nota kesepahaman adalah pernyataan tertulis yang merincikan kesepahaman awal dari pihak-pihak yang akan mengikatkan diri ke dalam suatu kontrak atau perjanjian lainnya. ${ }^{10}$

Sebelum kontrak disusun, ada empat hal yang harus diperhatikan oleh para pihak. Keempat hal itu meliputi: identifikasi para pihak, penelitian awal aspek terkait, pembuatan Memorandum Of Understanding (Mou), dan negosiasi.

a. Identifikasi Para Pihak berwenang membuat kontrak adalah orang yang sudah dewasa dan/atau sudah kawin. Tahap identifikasi para pihak merupakan tahap untuk menentukan dan menetapkan identitas para pihak yang akan mengadakan kontrak. Identitas para pihak harus jelas dan para pihak harus mempunyai kewenangan hukum untuk membuat kontrak.

b. Penelitian awal aspek terkait

Pada dasarnya, pihak-pihak berharap bahwa kontrak yang ditandatangani dapat menampung semua keinginannya sehingga apa yang menjadi hakikat kontrak benar-benar terperinci secara jelas. Perancangan kontrak harus menjelaskan hal-hal yang tertuang

${ }^{10}$ Rosa Agustina, op.cit, hal. 87 
dalam kontrak yang bersangkutan, konsekuensi yuridis, serta alternatif lain yang mungkin dapat dilakukan. Pada akhirnya penyusunan kontrak menyimpulkan hak dan kewajiban masingmasing pihak, memperhati-kan hal terkait dengan isi kontrak, seperti unsur pembayaran, ganti rugi, serta perpajakan. $^{11}$

c. Pembuatan Memorandum of Understanding (MoU)

Istilah Memorandum Of Understanding berasal dari dua kata, yaitu memorandum dan understanding.

Secara gramatikal memorandum of understanding diartikan sebagai nota kesepahaman. Dalam Black Law Dictionary, yang diartikan memorandum adalah: "is to serve as the basis of future formal contract." Yang terjemahannya ke dalam bahasa Indonesia adalah "dasar untuk memulai penyusunan kontrak secara formal pada masa datang.” Sedangkan understanding diartikan sebagai: "An implied agreement resulting from the express term of another agreement, whether written or oral." Artinya, pernyataan persetujuan secara tidak langsung terhadap hubungannya dengan persetujuan lain, baik secara lisan maupun secara tertulis." Munir Fuady,

\footnotetext{
${ }^{11}$ Salim HS, op.cit, hal. 86
}

mengartikan Memorandum of Understanding sebagai berikut: "Perjanjian pendahuluan, dalam arti nantinya akan diikuti dan dijabarkan dalam perjanjian lain yang mengaturnya secara detail, karena itu, memorandum of understanding berisikan hal-hal yang pokok saja. Adapun mengenai lain-lain aspek dari memorandum of understanding relatif sama dengan perjanjian-perjanjian lain." 12

Erman Rajagukguk mengartikan memorandum of understanding (MoU) sebagai berikut ini: "Dokumen yang memuat saling pengertian diantara para pihak sebelum perjanjian dibuat. Isi dari memorandum of understanding harus dimasukkan ke dalam kontrak, sehingga ia mempunyai kekuatan hukum mengikat."13 Salim HS memberikan definisi memorandum of understanding (MoU) sebagai berikut ini: "Nota kesepahaman yang dibuat antara subyek hukum yang satu dengan subyek hukum yang lainnya, baik dalam suatu negara maupun antar negara untuk melakukan kerja sama dalam berbagai aspek kehidupan dan jangka waktu tertentu." 14

${ }^{12}$ Munir Fuady, 1997, Hukum Bisnis dalam Teori Dan Praktik, Buku Ke-4, Citra Aditya Bhakti, Bandung, hal. 91

13 Erman Rajagukguk, 1994, Kontrak Dagang Internasional Dalam Praktik di Indonesia, Universitas Indonesia, Jakarta, hal. 4

${ }^{14}$ Salim HS, op.cit, hal. 47 
$M o U$ merupakan suatu perbuatan hukum dari salah satu pihak (subjek hukum) untuk menyatakan maksudnya kepada pihak lainnya akan sesuatu yang ditawarkannya ataupun yang dimilikinya. Dengan kata lain, $M o U$ pada dasarnya merupakan perjanjian pendahuluan, yang mengatur dan memberikan kesempatan kepada para pihak untuk mengadakan studi kelayakan terlebih dahulu sebelum membuat perjanjian yang lebih terperinci dan mengikat para pihak pada nantinya. ${ }^{15}$

Secara internasional, yang menjadi dasar hukum adanya memorandum of understanding adalah Undang-Undang No. 24 Tahun 2000 Tentang Perjanjian Internasional. Dalam Pasal 1 huruf a Undang-Undang No. 24 Tahun 2000 Tentang Perjanjian Internasional. Perjanjian internasional adalah: "Perjanjian, dalam bentuk dan nama tertentu, yang diatur dalam hukum internasional yang dibuat secara tertulis serta menimbulkan hak dan kewajiban dibidang hukum publik."

\section{d. Negosiasi}

Negosiasi mempunyai kedudukan dan peranan yang sangat penting didalam mercang dan menyusun kontrak, karena

\footnotetext{
${ }^{15}$ Bimo Prasetio dan Asharyanto, 2013, "Perbedaan Antara Perjanjian dengan MOU", Serial Online, (diakses 21 Oktober 2019), available from : URL http://www.hukumonline.com/klinik/detail/lt514 689463d4b2/perbedaan-antara-perjanjiandengan-mou
}

tahap negosiasi merupakan tahap untuk menentukan objek dan subtansi kontrak yag dibuat oleh para pihak. Menurut Priyatna Abdurrasyid, negosiasi adalah: "Suatu cara dimana individu berkomunikasi satu sama lain untuk mengatur hubungan mereka dalam bisnis dan kehidupan sehari-hari."16

Ada beberapa tujuan dari sebuah negosiasi dalam bisnis, yaitu antara lain: ${ }^{17}$

1. Untuk mendapatkan atau mencapai kata sepakat yang mengandung kesamaan persepsi, saling pengertian dan persetujuan.

2. Untuk mendapatkan atau mencapai kondisi penyelesaian atau jalan keluar dari masalah yang dihadapi bersama.

3. Untuk mendapatkan atau mencapai kondisi saling menguntungkan dimana masing-masing pihak merasa menang (win-win solution).

\section{Aktualisasi Nilai-Nilai Pancasila} dalam Pembentukan Hukum

\section{Perjanjian Nasional}

Hukum Kontrak merupakan ketegori hukum yang meliputi kemanusian dan

16 Priyatna Abdurrasyid, 2002, Arbitrase \& Alternatif Penyelesaian Sengketa Suatu Pengantar, Fikahati Aneska, Jakarta, 21

17 Duwi Santosa, 2013, "Pengertian, Tujuan dan Manfaat Negosiasi”, Serial Online, (diakses 21 Oktober 2019), available from : URL : http://www.galeripustaka.com/2013/03/pengertia n-tujuan-dan-manfaat-negosiasi.html 
ekonomi sehingga untuk memahami transformasi Pancasila dalam kehidupan bermasyarakat, orang harus menganalisis pasal-pasal penuangan sila ke-1, ke-2, dan ke-5 yang berkaitan dengan hidup keagamaan, kemanusiaan dan sosial ekonomis. Asas konsensualisme menjadi dasar pembentukan perjanjian menurut sistem dalam Buku III KUH Perdata, yang mana asas konsesualisme merupakan bentuk penghargaan terhadap nilai-nilai kemanusian yang tertera dalam sila ke-dua pula. Bahwa sejak detik tercapainya kata sepakat tentang hal-hal yang pokok maka lahirlah perjanjian, meskipun dalam perjanjian tertentu disyaratkan formalitas seperti perjanjian perdamaian dan pendirian perseroan terbatas. Permasalahannya KUH Perdata tidak mengatur proses terjadinya kesepakatan melalui penawaran dan penerimaan.

Berdasarkan ketentuan Pasal 1338 ayat 1 KUHPerdata akibat hukum dari setiap perjanjian yang sudah memenuhi syarat sahnya perjanjian akan mengikat sebagai undang-undang bagi para pihak yang membuatnya. Jadi KUHPerdata hanya mengakui adanya hak dan kewajiban yang lahir dari hubungan kontraktual yang sudah terbentuk. Selanjutnya, dalam Pasal 1338 ayat 3 KUH Perdata ditegaskan bahwa perjanjian harus dilaksanakan dengan itikad baik. Karena sejatinya di Indonesia sendiri iktikad baik merupakan cerminan dari nilai- nilai pancasila itu sendiri yang kemudian di negara-negara dengan sistem hukum civil law seperti Belanda, Perancis dan Jerman sudah diakui bahwa itikad baik sudah harus ada pada tahap perundingan sebelum lahirnya kesepakatan, sehingga akibat hukum dari janji-janji pra kontrak diakui pula dan jika dilanggar menimbulkan akibat hukum. Karena perjanjian yang mengikat belum lahir maka gugatan yang diajukan untuk memperoleh ganti rugi dianggap sebagai perbuatan melawan hukum yang menimbulkan hak bagi pihak yang dirugikan karena kontrak tidak jadi dilahirkan, untuk memperoleh kompensasi.

Asas ini pula yang sebenarnya senafas dan senada dengan apa yang dikehendaki dalam Pancasila itu sendiri. Nilai-nilai saling memahami dengan hak-hak orang lain terlebih dalam perjanjian harus selalu dipegang tegus dalam implementasi nilainilai pancasila dalam rangka pembangunan hukum perjanjian nasional yang saat ini hendak digagas para segenap pemangku kepentingan.

Berdasarkan pertimbangan-pertimbangan diatas, bagi Indonesia dalam Undang-undang Hukum Perjanjian yang akan datang, perlu ditegaskan bahwa itikad baik sudah harus ada pada masa pra-kontrak sehingga janji-janji pra-kontrak diakui dan mempunyai akibat hukum. Yurisprudensi Indonesia belum mengakuinya, seperti dalam Putusan Mahkamah Agung No. 
2599/Pdt/2008 dalam kasus Linawati Tjiang melawan PT Sunter Agung Real Estate Development \& Construction dan putusan Mahkamah Agung RI No. 3138K/Pdt/1984, dalam kasus gugatan pembeli rumah atas janji-janji pra kontrak dalam brosur.

Hal lain yang perlu dipertimbangkan untuk mengemuka di dalam Undangundang Hukum Perjanjian Nasional, masih dalam kaitan dengan konteks prekontraktual ini, adalah asas umum dalam penetapan besarnya ganti rugi (kuantitatif) dan ukuran kualitatif untuk itu. Disarankan agar asas reasonableness (asas kewajaran) yang banyak digunakan didalam normanorma hukum perjanjian perdata internasional, digunakan juga di dalam Hukum Perjanjian Nasional. Penerapan dan perumusan asas reasonableness yang pada hakekatnya memang bersifat fleksibel diperlukan untuk memberikan ruang diskresi bagi hakim dalam menetapkan tingkat kewajaran di dalam setiap perkara yang dihadapi, dengan memperhatikan keadaan-keadaan yang relevan (relevant circumstances). Bagi Hukum Perjanjian Nasional, pemaknaan terhadap prinsip kewajaran itu harus dapat ditarik dari falsafah dasar yang mewarnai asas-asas hukum perjanjian nasional (Pancasila).

\section{KESIMPULAN}

Aktualisasi nilai-nilai pancasila dalam kerangka konseptual mampu menyentuh nilai dasar, nilai intrumental dan nilai praksis. Kesulitan aktualisasi nilai-nilai Pancasila dalam tataran praksis mempunyai tantangan tersenidri. Satu sisi Pancasila sebagai pandangan hidup bangsa (way of life), namun disisi lain ada beberapa deviasi-deviasi terhadapnya termasuk dalam hal ini deviasi nilai-nilai pancasila dalam praktek pra-kontrak. Pra-kontrak yang merupakan tahapan sebelum terjadinya kontrak sering dipermasalahkan karena tidak ada justifikasi terhadap pratek pra-konrak dalam hukum Nasional, sehingga kepastian hukum dan semangat kemanusian sebagai ejawantah nilai Pancasila sila ke-2 tidak tercemin dalam praktek pra-kontrak. Sudah barang tentu ketika kepastian hukum tidak mampu diakomodir, maka keadilan dan kemanfaatan yang disifati sila ke-5 tidak sama sekali tercermin dalam praktik tersebut. Selanjutnya iktikad baik yang terdapat dalam pasal 1338 ayat $3 \mathrm{KUH}$ Perdata, yang sejatinya asas tersebut merupakan pancaran nilai-nilai pancasila memang seharusnya dihadirkan dalam praktek pra-kontrak. Iktikad baik sendiri dalam praktek di negara-negara dengan sistem civil law memang hadir sebelum kontrak itu terbentuk, artinya hadir dalam 
tahapan pra-kontrak, termasuk dalam hal ini negara Indonesia yang mengedepankan nilai-nilai yang demikian untuk menjaga hak-hak kemanusian yang telah terlahir dengan adanya sebuah perjanjian bahkan sebelum perjanjian atau kontrak terbentuk.

\section{DAFTAR PUSTAKA}

Abdurrasyid Priyatna. Arbitrase \& Alternatif Penyelesaian Sengketa Suatu Pengantar. Jakarta: Fikahati Aneska. 2002.

Fuady Munir. Hukum Bisnis dalam Teori Dan Praktik. Bandung: Citra Aditya Bhakti. 1997.

Hatta Mohammad dkk. Uraian Pancasila. Jakarta: Mutiara. 1978.

Kusuma A.B. Lahirnya Undang-Undang Dasar 1945. Jakarta: Badan Penerbit Fakultas Hukum Universitas Indonesia. 2004.

Rajagukguk Erman. Kontrak Dagang Internasional Dalam Praktik di Indonesia. Jakarta: Universitas Indonesia. 1994

Rusli Hardijan. Hukum Perjanjian Indonesia dan Common Law. Jakarta: Sinar Harapan. 1998.
Yudistira. Aktualisasi dan Implementasi Nilai-Nilai Pancasila dalam Menumbuh Kembangkan Karakter Bangsa. Seminar Nasional Hukum. (Fakultas Hukum UNNES) Volume 2 Nomor 1 Tahun. 2016.

http://www.hukumonline.com/klinik/detail/ $\underline{\text { 1t514689463d4b2/perbedaan-antara- }}$ perjanjian-dengan-mou

http://www.galeripustaka.com/2013/03/pen gertian-tujuan-dan-manfaat$\underline{\text { negosiasi.html }}$

\section{BIODATA SINGKAT PENULIS}

Nama : Nursaiful Afandi

TTL : Malang, 25 April 1969

Pekerjaan : Aparatur Sipil Negara

Pendidikan Terakhir : DIV STPN Yogyakarta. Saat ini sedang menyelesaikan pendidikan S-2 Program Studi Magister Hukum di Universitas Narotama Surabaya. 